\title{
Toenemend kerk
}

H G van der Westhuizen

Hervormde Teologiese Opleiding

\begin{abstract}
The church - more and more

The Hervormde Kerk in Suidelike Afrika (Reformed Church in Southern Africa), the mission church of the Nederduitsch Hervormde Kerk van Afrika, must become increasingly a true missionary church in its own right by giving attention, inter alia, to the following aspects: extension of the church by way of life, building facilities, dimensional missions, student missions, attitude missions, structure missions, coming-of-age missions, prayer missions, youth missions, team missions, church dispersion missions, church naming missions, media missions, unitary missions and truth missions.
\end{abstract}

\section{A D PONT EN SENDING}

By die emeritaataanvaarding van prof A D Pont, herinner skrywer hom dat hy by prof Pont se voorganger, prof S P Engelbrecht, wat toe dekaan was, as student van die Hervormde Kerk ingeskryf het. Drie jaar van kerkgeskiedenis aan die voete van die jeugdige Pont is onvergeetlik, want sy teologie was nie slegs vakgebonde nie. Die dag staan nog helder in herinnering toe prof Pont ná 'n Kerkregstudie van ons, aanbeveel het dat doktorale Kerkregstudie later oorweeg moet word.

Pont se teologie was altyd kerkgerig en verbondsmatig. Sy spektrum van belangstelling is breed en diep en raak sowel volk as kerk. Ook die sending het in sy belangstellingsveld, veral op historiese en kerkregtelike terreine, verskyn. Histories het Pont voortdurend die Hervormde Kerk se aversie teen die vermeende sending van buitelandse genootskappe - wat gewere teen Boere in plaas van die evangelie vir heidene voorsien het-blootgelê. Kerkregtelik het hy 'n enorme bydrae gelewer 
met sy uitgewerkte en gefundeerde voorstel op 16 Mei 1962 (vgl Van der Westhuizen 1990:48). Hiervolgens is die Hervormde Kerk se sendingwerk gedesentraliseer na ringsuperintendente vir sending. Sedertdien het die sending 'n vaste patroon en koers ontwikkel. Hierdie bydrae het gevolglik ook 'n groot inset gelewer om die sendingkerk in sy kerkregtelike en ordelike uitbreiding te help.

Steeds moet ons bedink hoe die sendingkerk geadviseer en bygestaan kan word om toe te neem in sy kerkwees. Die paar gedagtes wat nou in hierdie verband aangestip sal word, word met dankbare vermelding van A D Pont se aanvanklike bydrae gedoen.

\section{KERKBOU IS OPBOU EN UTTBOU}

Die Hervormde Kerk in Suidelike Afrika (HKSA) is die sendingkerk wat uit die Nederduitsch Hervormde Kerk van Afrika (NHKA) se sendingwerk georganiseer is (Van der Westhuizen 1990:23-36). Omdat die HKSA kerkregtelik 'n selfstandige kerk is, moet dit self ook sendende kerk wees. So 'n sendende of missionêre kerk hoef nie altyd gelowiges net uit te stuur, dit wil sê ver weg te stuur, om sendingwerk te doen nie: Wanneer die kerk in sy Jerusalem of Judea of Samaria of tot aan die eindes van die aarde sending doen, is hy missionêre kerk. Sending is ook nie net georganiseerde sending nie, maar spontane individuele evangelisering is ook sending tewens, dit is basiese sending.

Daar is ook vir die HKSA op sy drumpel 'n groot sendingveld - indien onder sending die kommunikasie van die kennis van die enigste ware God en Jesus Christus wat Hy gestuur het - kennis wat die ewige lewe is - verstaan word (Joh 17:3). Onder die miljoene mense wat rondom die HKSA leef, is daar soveel'Rooms-Katolieke, lidmate van die Onafhanklike Kerke, onaanvaarbare sektariese kategorieë, aanhangers van die tradisionele godsdienste van Afrika en mense met ' $n$ baie dun vernissie van Christelikheid wat lidmate van aanvaarbare denominasies is (Van der Westhuizen 1990:147-153). Sonder om skaapdiefstal of proselietmakery te pleeg, is daar nog 'n enorme sendingtaak binne ons landsgrense.

Dit is nie so dat 'n denominasie sekere dinge moet doen om 'n missionêre kerk te wees nie. Indien ' $n$ denominasie 'n openbaring is van die een heilige algemene Christelike kerk, is dit eerder dit wat die kerk moet wees, wat die kerk is, wat van hom missionêre kerk maak. Die wese van die kerk is Christus - die hoof van die kerk. Die wesensfunksies van die kerk is sy dissipelmatige oftewel sy pastorale koninklike, priesterlike en profetiese funksies en sy apostolère profetiese, priesterlike en koninklike funksies. 
Indien 'n denominasie deel van die kerk van Christus is, moet dit dus apostolêr funksioneer. Die apostolaat is net so 'n wesenskarakter van die kerk as die dissipelmatige wesenskarakter. Die pastorale en die missionère is die 'kom' en 'gaan' van die kerk. 'n Kerk wat staan word soos Lot se vrou 'n soutpilaar en is nie meer die sout van die aarde nie. 'n Kerk wat sonder Christus gaan, is sout wat verslaan het. Dit is niks meer werd nie. Dit word buitekant weggegooi en die mense vertrap dit (Matt 5:13). Die kerk is die liggaam van Christus op aarde wat Christus navolg èn deur Christus gestuur word (Van der Westhuizen 1990:4-15).

Die HKSA - of enige denominasie - moet nooit na sy hande of handewerk kyk om vas te stel wat hy nog moet doen om missionêre kerk te word nie. Maar 'n kerk moet sy hande in eie boesem steek en sy kerkwese ondersoek of hy 'n missionêre kerk is. Kerkwyse hang van kerkwese af; kerklike handelinge is in die kerklike hart gegrond - of daar hartlik in ooreenstemming met die kerk se hoof, Jesus Christus, gehandel word.

Wanneer vervolgens 'n paar aanbevelings bespreek word om die HKSA missionêr te ontplooi, word dit nie as bykomend by die kerk nie, maar as voortkomend uit die kerk aanbeveel. Die stuk of vyf en twintig punte van sendingmetodes wat elders reeds genoem is ( $V$ an der Westhuizen 1990:41, 42), word nie hier herhaal nie. Die kerk moet hartlik missionôr wees, dan sal sy handele dit ook wys. Die intensiewe toename van kerkwees sal die ekstensiewe groei beïnvloed. So moet ook die HKSA toenemend kerk wees. Kerkbou is opbou en uitbou van die kerk in die wêreld.

\section{OPLEIDINGSENDING}

Grondige teologiese opleiding in 'n egte inheemse konteks deur dosente van die HKSA self, is noodsaaklik.

Die verskillende teologiese departemente aan die Fakulteit Teologie moet almal 'n duidelike missionère dimensie in elke vakaanbieding openbaar. Die Departement Sendingwetenskap moet intensioneel missionêr wees. Dit mọet praktykgerig wees. Dit kan egter alleen bevredigend geskied wanneer die ander departemente die missionère dimensie voldoende blootlè.

Die opleiding van spesifiek sendelinge of evangeliste moet ernstig oorweeg word. Die opgeleide persoon as 'n frontliniepersoon moet 'n generaal in die worstelstryd (Ef 5:10-28) wees wat kundig, eerlik en dapper die vyand van die Here en van die kerk van die Here tegemoet tree.

Die deeglikheid van die sendingwerker se opleiding - selfs beter as 'n gewone leraar se opleiding - moet nie maar net aan grade en diplomas gemeet word nie. Daar is ' $n$ verklaarbare neiging onder swartmense om 'n hoë premie te plaas op 
grade, status en wêreldwye aanvaarding. Dit is egter goed om in gedagte te hou dat die kerk nie met wêreldkrag, status en grade funksioneer nie maar deur die Gees van God met opregtheid, toegewydheid, waarheid en die besef van eie swakheid (1 Kor 4:20; 2 Kor 12:9).

\section{GEBOUESENDING}

Swartmense identifiseer met konkrete dinge. 'n Kerk wat nie sy kerkgebou kan wys nie, is onmagneties. So 'n geboulose organisasie word as een of ander stamverskynsel ('tribalism') of 'n sekte beskou. Dit is waar dat 'n Christen moet weet dat die lidmate van 'n kerk - en nie die gebou nie - die een heilige algemene Christelike kerk vorm. Die argument gaan egter in die geval waar die HKSA met sending begin nie oor Christene of ware Christene nie. Omdat daar gemeentes van die HKSA is wat reeds jare bestaan en sonder geboue moet funksioneer, is hierdie versugting na fasiliteite juis so akuut. Dergelike gemeentes groei nie vermeldenswaardig nie.

Die leraar van 'n geboulose gemeente word dikwels nie as 'n betroubare persoon gesien nie, maar as iemand wat sonder sekuriteit van geboue aan die gemeentelede homself wil verryk.

\section{DIMENSIONELE SENDING}

Die verhouding tussen God en die wêreld moet aan die swartmense grondig en duidelik gestel word. Dat sonde die ver en verkeerd wees teenoor God is, die versteurde verhouding tussen God en sy skepping via die mens is en dat die yerhouding tot God alleen via Christus herstel word, moet helder gefokus word.

Die religieuse infra of geloofsonderbou van die tradisionele godsdienspatrone van die swart wêreld moet ingrypend deurbreek word. Indien dit missionèr suksesvol gedoen word, voorsien die nuwe blye boodskap 'n nuwe lewensbeskoulike onderbou wat as bakermat in die gelowige se hele lewensintegriteit dien. Dan eers kan daar van kerstening gepraat word. Dan sit daar 'n missionêre dimensie in die gelowige se hele handel en wandel, in die gemeenskap van die gelowiges se hele bestaan, in al die organisasies, komitees, rade en vergaderings van elke gemeente en sy verenigings.

Veral ampsdraers sal elkeen deeglik toegerus moet word om evangeliserende gesprekke te kan voer. Hulle moet ook, in aansluiting by die toerustende prediking. die gemeentelede toerus om spontane sendelinge in hulle eie omgewing en werk te kan wees (Ef 4:11, 12). Om Goliat aan te vat moet Dawid egter nie in Saul se har- 
nas kom nie maar met sy slingervel en vyf gladde klippies gewapen wees (vgl Van Rooy 1990:283-294; Van der Westhuizen 1990:140).

Om die missionêre dimensie van elke komponent van die gemeente te versterk tot effektiewe funksionering, moet lidmate wat met een of ander gawe in hierdie verband begenadig is, geïdentifiseer en benut word (Rom 12:6; 1 Pet 4:10). Die missionêre dimensie van die HKSA kom in sy Kerkwet wel na vore. In artikel 4 wat handel oor die roeping van die kerk, staan dat dit: 'Die roeping van en opdrag aan die kerk van Christus is...4.5 die verkondiging van die evangelie aan die wat daarvan vervreemd is en verder aan die ganse mensdom....'

Oor die priesterskap van die gelowiges (vgl Van der Westhuizen 1990:85-89) stel die Kerkwet in artikel 8: 'Ter vervulling van die roeping van die priesterskap van die gelowiges, word die lidmate van die kerk geroep om die ampsdraers by te staan in die diens van die kerk, en naas hulle werksaam te wees in die apostolaat, die geestelike vorming van die jeug, die kategese en die diakonaat.'

Artikel 9 handel oor die apostolaat van die kerk:

As Christusbelydende kerk in die wêreld, vervul die Kerk sy opdrag in gehoorsaamheid aan die bevel van Christus: 'Gaan dan heen, maak dissipels van al die nasies en doop hulle in die Naam van die Vader en die Seun en die Heilige Gees en leer hulle om alles te onderhou wat Ek julle beveel het" (Matt 28:19, 20) deur voortdurend te arbei aan die evangelisering van die persone uit die heidendom, sektes en Roomse, die hervorming van die eie kerk, sodat almal kan hoor van die verlossing wat in Jesus Christus is, om dit met die ewige heerlikheid te verkry.

Soos in die ander artikels en bepalings is die ooreenkoms met die Kerkwet van die NHKA ook in artikel 9 opvallend. Opmerklik is dus ook dat die HKSA nie 'n belydeniskerk is nie maar soos artikel 9 stel, 'n belydende kerk.

Bepaling 32 van die Kerkwet van die HKSA detailleer die apostolaatsartikel verder:

32.1 Dit is die Kerk se roeping en plig om die evangelie van Jesus Christus te verkondig aan alle mense en buitekerklikes wat vreemd staan teenoor die evangelie.

32.2 Die gemeente en elke lidmaat is geroepe om die evangelie van Jesus Christus uit te dra in die eie omgewing.

32.3 Die kerkraad sien dit as sy opdrag om die evangelie van Jesus Christus onder buitekerklikes, kerkvervreemdes en heidene uit te dra. Die kerkraad sal leiding neem in en verantwoordelik wees vir die werke van die Kerk. 
Met die oog op die missionêre dimensie van die HKSA is dit belangrik om op bepaling 32.2 hierbo te let: Elke lidmaat moet te alle tye 'sendeling' wees.

\section{STUDENTESENDING}

Studente wat vir leraars in die HKSA by die Hervormde Teologiese Opleiding (HTO) studeer, moet met die oog op praktiese vereistes in hulle opleiding vakansiewerk in 'n gemeente doen. Hulle is dikwels baie ywerig om ongelowiges tot geloof te roep.

Hierdie sendingwerk het baie keer geen opvolging nie. Leraars wat wel weet wat om te doen, het dikwels die verskoning dat hulle reistoelaag, werksdrukte of bykomende werk hulle nie toelaat om die nuwelinge dadelik of ooit op te soek nie. Miskien moet daar 'n skakelingsnetwerk tussen HTO, die missionerende student, die leraar, sy gemeentelike sendingkommissie, kerkraad of sendingdiensgroep en die HKSA se sinodale evangelisasiekommissie opgebou word.

Dit moet dan oorweeg word om die studente of 'n groep studente nie gemeentewerk te laat doen nie, maar volledige sendingwerk. 'n Groep studente van drie of vier kan selfs as ' $n$ span na 'n sekere omgewing gestuur word. Met die nodige opvolgingswerk kan aldus baie sukses behaal word.

Studente van HTO doen reeds so ver hulle per voet en te fiets kan reik, sending in die omgewing van Klipdrif waar die opleiding geleë is.

Die verskillende nabyliggende ringsendingrade kan meer binne die akademiese jaar van studente gebruik maak om sendingprojekte te onderneem.

\section{GEDRAGSENDING}

Indien persone nie getrek word deur die geloofwaardigheid van veral voorgangers nie, sal dit slegs 'n wonder wees indien daardie gemeente sal groei. Leraars moet reggeaard wees. Die leraars moenie die base in gemeentes wees nie, maar dienaars wat as bedienaars van die Woord op 'n kragtige en kragdadige wyse wys na die enigste Baas, Jesus Christus (1 Kor 4:1).

Omdat ons in 'n tyd leef waarin so baie rowers en kwaaddoeners onder 'n kerklike of 'n priesterlike kleed hulle boosheid of eie planne of selfs politiek wil bevorder, moet ampsdraers se integriteit bo alle twyfel bevestig word.

Die apostel Paulus het eerder homself onderhou as om die indruk by die gemeente te skep dat hy met die Woord handel dryf - hoewel hy geregtig was om van die Woord te lewe (Van der Westhuizen 1977:121-124). Ook wou hy 'n voorbeeld wees van handearbeid. 


\section{STRUKTUURSENDING}

Die beroeppraktyk in die HKSA is grootliks 'n hindernis vir die uitbreiding van die kerk.

Juis in 'n sendingsituasie moet die sendeling van mens tot mens en van gemeenskap tot gemeenskap beweeg. In die HKSA egter sit elke leraar in sy gemeente asof hy daarmee getroud is. So 'n sittende leraar word nooit na 'n ander gemeente beroep nie. Die vakante gemeentes moet maar wag tot daar 'n student afstudeer of totdat ' $n$ leraar se posisie in 'n bepaalde gemeente volkome onhoudbaar geword het!

Soos die HKSA in die geheel, moet elke gemeente strategiese beplanning met vasgestelde doelwitte met die oog op sending hê. Hierdie doelwitte moet nie so ver in die toekoms of so wyd in omvang wees dat dit nie met sigbare sukses stuk-stuk binne haalbare moontlikhede verwesenlik kan word nie.

Voordat die HKSA nie sy eie sinodale fasiliteite, kerkkantoor, administratiewe personeel en administrateur het nie en/of wat in hierdie verband deur die betrokke denominasie alles benodig word nie, sal hy nie struktuurdissipline kan aanleer nie en sal hy ook soos baie gebreklike afhanklikes gedurig worstel met sy selfbeeld.

\section{MONDIGHEIDSENDING}

So lank die HKSA massas geld van die NHKA moet ontvang, so lank die HKSA na die NHKA opsien vir dosente en opleiding, so lank die HKSA na die NHKA opsien om sy struktuur te bou, sy vergaderings te help reël en te help prosesseer, sy publikasies tot stand te bring, sy kerkadministrasie te huisves en so meer, so lank sal die HKSA ' $n$ identiteitskrisis beleef.

Hierdie identiteitskrisis strem groei. Indien 'n baba nooit sou ophou om deur sy moeder gesoog te word nie, word sy groei belemmer. Dit is teen alle natuurlikheid in dat ' $n$ baba tot sy volwassenheid en tot sy ouderdom toe aan sy moeder se bors drink.

Die soogkompleks voed die gedagte dat die HKSA te arm is om sending te doen. Paulus was nie ryk nie. Paulus was egter geestelik ryk. Dit is uit hierdie geestelike rykdom waar sending ontspring.

Die eerste gemeentes van die Nuwe-Testamentiese tyd was materieel op dieselfde vlak as wat die HKSA vandag is. Hulle was so arm dat die produk van hulle sendingwerk hulle soms finansieel 'n bietjie gehelp het. Tog het hulle in hulle materiële armoede sending gedoen.

'n Gemeente of 'n kerk wat nie 'n gesonde trots op grond van 'n egte dankbaarheid teenoor God het nie, het 'n gebreklike selfbeeld en 'n gebreklike dryfkrag. 
Lidmate van so 'n kerk van wie die Christus beskouing nie volkome helder is dat Christus die Hoof van die kerk en die Heer van die wereld is nie, is swak en vaag in hulle belydenis en belewenis hiervan. Die HKSA lewe inderdaad in 'n wêreld van oorwegend arm mense. Tog is daar 'n groeiende opkomende groep wat finansieel daar beter aan toe is. Die leraars self wat ' $\mathrm{n}$ redelike traktement en reiskoste kry, gaan dikwels self nie die gemeente voor in voorbeeld om voldoende dankoffers te gee nie en leer die gemeente hiertoe ook nie andersins nie. Inteendeel, baie leraars is voortdurend besig om een of ander bykomende inkomstetjie te verkry. Dit reflekteer in baie opsigte sleg op die gemeente.

Die hele saak van dankoffers moet aan die leraars en deur die leraars aan die ampsdraers en ook deur hulle aan die gemeente verduidelik word. Dit kan en moet op ' $n$ wyse gedoen word dat daar dankbaarheid en blydskap ontstaan. Dan kan dié geleenthede self missionêr wees.

God het net een Seun gehad en dié het $\mathrm{Hy}$ as sendeling gestuur - soos David Livingstone gesê het. In die rykdom dat ons aan Jesus aan wie alle mag in die hemel en op die aarde behoort (Matt 28:18), aan wie die aarde en alles wat daarop is, behoort (Ps 24:1), moet en kan ons selfs sonder goud of silwer of koper of reissak of ekstra skoene en klere, sending doen (Matt 10:9).

\section{GEBEDSENDING}

Met sterfgevalle onder heidene of selfs onder Christene, kom daar altyd ongelowiges op besoek. Hierdie geleenthede moet as gebedsgeleenthede benut word. Ook ander gebedsgeleenthede moet gesoek of geskep word. Met die nog daarop moet die inhoud van die gebed baie noukeurig in die lig van die Woord oorweeg word. Daar moet grondige studie wees oor die gebed as missionère instrument.

Ons moet altyd onthou wat ons in die Heidelbergse Kategismus in Sondag 45 bely dat 'God sy genade en Heilige Gees alleen aan hulle wil gee wat Hom met hartlike versugtinge sonder ophou daarom bid en daarvoor dank'. Van hierdie een gebedsaak is ons verseker: 'Hy sal die Heilige Gees gee vir dié wat vra' (Luk 11:13).

\section{KINDERSENDING}

Kinders is altyd in hulle verskillende opvoedingsfases st erk beinvloedbaar.

Kerkkinders kan op vermaaklike en vergoedende terme as sendinggroepe georganiseer word. Seunsgroepe en dogtersgroepe, padvinders ('boy scouts' en 'girl guides') kan vir die massas 'n aantrekkingskrag wees om deel te word van die kerk. Kinders van die HKSA kan as 'n soort Kinderkrans vir die sending toegerus word. 
Die HKSA-leraars moet voortdurend na sleutelgeleenthede soek om met skoolhoofde of onderwysers te skakel om toegang tot kinders te verkry.

Nie alleen omdat kinders in die swart wêreld die grootste bevolkingskomponent vorm nie, maar ook omdat Jesus die kinders uitnooi om na Hom te kom - weliswaar verbondskinders (Matt 19:13-15; Mark 10:13-16; Luk 18:15-17) - moet dringende missionêre aandag aan die kinders en die jeug gegee word.

\section{SANGSENDING}

By nagwake, eredienste, byeenkomste en prosessies na geleenthede soos hoeksteenlegging, kerk- en pastorie-inwydings, belydenisgeleenthede, sakramentsgeleenthede en so meer moet daar hartlik en met duidelike diksie evangelies gesing word.

Swartmense hou van sang en sing graag saam. Die wysie en die woorde moet eenvoudig, treffend en herhalend wees. Moeders en kinders, werkers en individuele gelowiges in missionêre konteks kan deur sang 'n evangeliese boodskap plant.

Musiekkompetisies - nogal 'n gewilde verskynsel onder swartes - kan op velerlei wyses sendingmatig benut word. Omdat sang nie net aantreklik is nie, veral vir die swartmense, maar inderdaad die gees en gemoed van die mens voorberei om vrugbare aarde vir die saad van die Woord te wees (vgl Van der Westhuizen 1976: 43-50) moet die HKSA 'n noukeurige missionère instrument daarvan maak.

\section{KERKVERSPREIDINGSENDING}

Ons tyd word gekenmerk deur geweldige woonplekverskuiwings. Verstedeliking van die swartes is een van die grootste sosiale verskynsels van ons tyd. Swartes as individue moet ook dikwels van die een plek na die ander beweeg om werkgeleenthede te soek.

Indien dit 'n lidmaat van die HKSA is, behoort hy/sy in die nuwe woonplek deur lidmate van sy oorspronklike HKSA-gemeente besoek te word. Hierdie kontak moet behou en uitgebou word sodat daardie Hervormde lidmaat in die vreemde 'n huiskerk kan vorm waarby nuwe vriende kan inskakel.

Indien die HKSA-lidmate besondere gasvryheid bied met 'n sterk uitlewing van hulle besondere kerkverband, sal dit nie alleen missionère vrugte oplewer nie, maar dit sal ook aansluiting in die Bybel vind.

Die vroeë kerk in die tyd van die Nuwe Testament was deur vervolging verstrooi (bv Hand 11:19). Handels- en ander reise het hulle ook op primitiewe vervoerwyses te voet of per donkie na mense gebring waar gasvryheid beoefen is. Soos ' $n$ vader sy gesin in alle behoeftes moet versorg, moet hy as 'n gemeentevader met 
gasvryheid in die midde van sy gemeente verkeer. So is die huisgemeentes in besonder geraak. Ampsdraers in die besonder word deur die eerste brief aan Timoteus tot gasvryheid en goeie gesins- en gemeentebeheer opgeroep (1 Tim 3:2, 4).

Lidmate van die HKSA wat om een of ander rede versprei oor ander gebiede, moet dus steeds hulle Christenskap ook in hulle kerkverband uitleef. Ook lidmate by wie ander 'n deurgangsverblyf of 'n deurgangsbesoek vind, moet hulle geloof deur hulle gasvryheid meedeel.

\section{KERKNAAMSENDING}

In die tyd van die Nuwe Testament was dit nie nodig dat die kerk 'n onderskeidende naam kry nie. Die kerk self was onderskei van enige ander organisas' e. Die woord 'gemeente' of 'kerk' alleen het self as onderskeidende naam gegeld (bv Hand 2:47; 5:11). Nadat die kerk ook na ander plekke uitgebrei het, is die kerk van die een plek, van die kerk van 'n ander plek onderskei, deur die pleknaam by die kerk te noem, byvoorbeeld die 'gemeente/kerk in Jerusalem' (Hand 8:1) of die 'gemeente/ kerk van die Tessalonisense' (1 Tess 1:1; 2 Tess 1:1).

In ons tyd word kerke nie meer net met geografiese name onderskei nie, maar ook met historiese, kultuur- en geesverwantskap benaminge.

' $n$ Spesifieke naam van ' $n$ denominasie is dus nie ' $n$ wet van Mede en Perse nie. Die HKSA het immers ook self met sy selfstandigwording in 1977 op die naam HKSA - wat verskil van vorige benaminge - besluit.

Dit blyk dat die naam 'HKSA' om verskillende redes nie juis meewerk tot ontvanklikheid van die kerk in die swart gemeenskappe nie.

Swartes wat die naam hoor en dit dadelik in Engels vertaal, differensieer met 'n gebrekkige of geen kerkgeskiedeniskennis baie moeilik tussen NGKA en HKSA. Albei is in Engels 'reformed' met die vermelding en die vermoede van 'Dutch'. Waar daar in 'n bepaalde gemeenskap dus reeds 'n Nederduitse Gereformeerde Kerk is, word die HKSA baie moeilik onderskei en aanvaar.

Die Hervormde deel van die HKSA se naam verbind natuurlik hierdie kerk onmiddellik aan die NHKA. Alhoewel die HKSA kerkregtelik selfstandig is, assosieer die swart publiek hierdie kerk sonder meer met die NHKA. Gewoonlik word heel gou bevind dat die NHKA, die Christusbelydende volkskerk in die blanke Afrikanervolk, die artikel III het wat lidmaatskap volksgewys oriënteer. Die meeste swartes wat vandag deur politieke propaganda in kerklike en teologiese verwarring hulle weg moet vind, vind artikel III onbegryplik en verwerplik. Assosiasie met hierdie kerk weens historiese en finansiële bande maak die kerk met 'n soortgelyke naam dan onaanvaarbaar. Derdens is die Afrikaanse naam van die HKSA log nie as 
vreemuheid in 'n ander taalgroep tuis nie. Ook hier moet die inheemsheid realiseer. In hierdie opsig sou enige naam maar net vertaal kon word.

Miskien moet die HKSA dit oorweeg om 'n naam te vind waarin 'hervormd' of 'reformed' glad nie voorkom nie, byvoorbeeld die 'Evangeliese Kerk van God' in die verskillende vertalings. Om die kerk as evangelies te kwalifiseer, is in ons tyd met sy vele kerkopvattings sekerlik nodig. Die uitdrukking 'kerk van God' kom in die Bybel baie voor (bv 1 Kor 10:32; 11:16, 22; 15:9; 2 Kor 1:1; Gal 1:13; 1 Tess 2:14; 2 Tess 1:4).

As 'n naam 'n mens laat struikel en dit is nie die naam van Jesus Christus nie, moet dit verander word.

\section{SPANSENDING}

Behalwe dat studente in spanwerk met die oog op sendingwerk in vakansietye en andersins naby die HTO ingespan kan word, moet ook aan die vorming van ander sendingspanne gedink word. Hier word nie net aan een of ander tipe veldtog tydens geleë geleenthede gedink nie. Spanne as 'n voortdurende benaderingstipe moet oorweeg word. Veral swartmense het 'n sterk solidariteitsgevoel. Individue sluit geredelik by groepsvorming aan.

Soos ' $n$ individu teenoor ' $n$ individu die blye boodskap kan verwoord en vóorleef, so moet 'n gesin dit teenoor 'n gesin doen en 'n dorpie of stat teenoor 'n ekwivalente gemeenskap.

'n Kerkraad as groep of die jeugvereniging of die kategeseskool of die vrouevereniging of die gemeentelike of ringsendingvereniging $k a n$ in geheel ' $n$ bepaalde sendingprojek aanpak.

Omdat vrouens, veral in plattelandse gebiede, bedags alleen met hulle kinders tuis is, is dit belangrik dat die sendeling of leraar of groep nie slegs uit mans sal bestaan nie. Missionerende studente, evangelis, leraar, individu of groep moet van vroue vergesel wees.

'n Span wat ook uit getroude persone bestaan, kan spesifiek vir sendingwerk toegerus word - selfs met behulp van HTO. lemand in die span moet ook die doop kan bedien. Uit die span se ervaring kan verstellings en verbeterings aan hulle toerusting aangebring word. Uit so 'n professionele sendingspan kan ervaringskennis ook aan studente en aan gemeentelike sendinginstansies oorgedra word.

Die sendingspan kan by spesiale geleenthede met een of ander komponent van hulle sending opereer, byvoorbeeld sangsending, getuienissending en so meer. Die sendingspan kan ook self sendingdienste organiseer wat tot deurslaggewende aangeleenthede kan uitbrei. 
Die onderhouding van so 'n sendingspan kan per afspraak deur sowel die HKSA as die NHKA gedoen word.

Spanwerk sal tot spanproduk lei. En dit bly waar dat 'n enkele mieliepit nie tot 'n mielieplant en 'n mieliekop en baie mielies sal uitgroei indien hemel en aarde nie saamwerk nie. Soos die aarde sy vrugbare grond, klipdreinering en die hemel sy reën, sonskyn en albei hemel en aarde hulle saamgestelde klimaatstoestand en temperatuur moet gee, so moet sendingwerk inderdaad spanwerk wees.

Die feit van medewerkers van en evangeliste in die tyd van die apostels, is geleë in die sending as gemeenskapsaak. Die woord 'gemeente' druk hierdie gemeenskapswerk ook uit en so ook ons belydenis van die gemeenskap van die heiliges. Jesus het nie alleen gewerk nie, maar Hy het twaalf dissipels gehad (Heb 3:1; Joh 20:21; Mark 3:13-19). Die sewentig dissipels is twee-twee uitgestuur (Luk 10:1). Petrus gaan in die geselskap van medebroers van Joppe na Sesarea (Hand 10:23; 11:12). Barnabas en Paulus is saam op die eerste sendingterrein (Hand 13:2-5). Barnabas gaan saam met Johannes Markus, ná 'n geskil met Paulus, na Siprus terug, terwyl Paulus met Silas as sy medewerker op die tweede sendingreis vertrek (Hand 15:39-41). Op die derde sendingreis is Paulus omring van medewerkers (Hand 19: $7,10)$. Die medewerkers en evangeliste is assistente of helpers van die apostels soos die helpers of bodes van 'n hof (Matt 5:25; Luk 4:20). Die apostels was ook so die assistente van Christus (Hand 26:16; 1 Kor 4:1). Sendingwerk is nie 'n eensaamheidswerk nie (Van der Westhuizen 1982:225-231).

\section{MEDIASENDING}

Aangesien daar onder die jeug van die swart wèreld 'n skoolontploffing is, sal miljoene binnekort kan lees. Hierdie vermoë om te lees saam met die bekende mag van die pen moet sendingmatig benut word.

Die HKSA self moet begin met 'n goedkoper tipe inligtingspamflette, evangeliese biljette met adresse daarop. geestelike leiding en geloofsvoeding in die vorm van brosjures. Hierdie ligter literatuur moet opgevolg word met oordenkings, Bybelbeligtings en lewensprobleme in verlossingsverband gesien.

Bestaande literatuur soos die Almanak, die tydskrif Montshafatsi en so meer moet nie net amptelike gegewens bevat nie maar missionér georiënteer word. Dit kan sendingmatige kompetisies bevat. Die swart jeug is lief om aan kompetisies, veral waaraan 'n vergoedinkie verbonde is, deel te neem. Pogings kan aangewend word om by die bestaande dagbladpers of tydskrifte by wyse van briewe of rubrieke of berigte die sending te bevorder. 
Gemeentelede, kerkraadslede, groeplede (jeugvereniging, sustervereniging, Amadodana-mannevereniging, kategeseskool ens) en posverspreiding, massaverspreiding by saamtrekke, bushaltes, hostels, hospitale en sportbyeenkomste kan diensbaar in die literatuursending wees. Kassette, grammofoonplate en die moderne media, koerante, radio, televisie ensovoorts moet waar moontlik betrek en benut word.

\section{EENHEIDSENDING}

Daar is steeds die gedagte onder kerkmense ook en veral van die swart wêreld dat organisatoriese vereniging sal help om sending te bevorder. Aan die ander kant kry ons egter dikwels 'n baie sterk selfgerigtheid by die onderskeie kerke.

Dit is egter ' $n$ vraag of ' $n$ mens wanneer jy jakkalse gaan jag meer jakkalse met een leeu as met tien honde sal jag. Dat die leeuehart egter in elke hond waarneembaar moet wees, is belangrik.

Wanneer Jesus bid om die eenheid van sy dissipels of kerk, sodat die wèreld kan glo dat Jesus van die Vader af gestuur is (Joh 17:21), handel dit nie oor organisatoriese vereniging nie. Organisatoriese vereniging beteken identiteitsverlies van die betrokke kerke. Maar Jesus bedoel in sy gebed van Johannes 17 hoegenaamd nie enige identiteitsverlies nie. Die voorbeeld wat $\mathrm{Hy}$ vir die gebedseenheid gebruik, is 'dat hulle almal een mag wees, net soos U, Vader, in My is en Ek in U, dat hulle ook in Ons mag wees...' (Joh 17:21). Die eenheid tussen Jesus en sy Vader vereis nie identiteitsverlies van die Seun of die Vader nie, ook nie 'n identiteitsverlies tussen die Vader en die Seun, die 'Ons' aan die een kant en die dissipels, die 'hulle' aan die ander kant nie.

Honde moet nie saam een leeu word vir die sendingjag nie. Almal moet egter een in leeuehart word - een in hart en sin, een in waarheid, een in gesindheid, een in samewerking. Hierdie eenheid sal inderdaad die sending bevorder. Wanneer'n heiden dieselfde boodskap, dieselfde gees en dieselfde gesindheidheid by verskillende denominasies waarneem, sal hy juis uit die veelheid van getuienisse met 'n eenheidsinhoud kan glo dat daar 'n enkele oorsprong van hierdie boodskap is, naamlik dat dit die Vader is wat Jesus gestuur het, dat die kerk geestelik die aardse liggaam van Jesus is.

\section{WAARHEIDSENDING}

Dit sou die koninkryk van God niks haat indien 'n kerk in getalle toeneem omdat die toenemende getalle een of ander nut op humanistiese vlak in dié kerk sien nie. 
Aan die ander kant is dit seker ook nie noodwendig vir die koninkryk skadelik indien 'n denominasie klein bly net omdat sy evangelie en onderliggende teologie waar en suiwer is nie.

Die HKSA leef in 'n wêreld en in 'n tyd dat daar baie teologiese sywasse, terugwasse en dwarswinde is. In die wêreld waarin die HKSA kerk moet wees, is dit aantreklik om in die Swartteologie, die Bevrydingsteologie en die Revolusieteologie te verval. Hierdie kontekstuele teologieë is inderdaad dan ook geweldig bedrywig binne die sfeer van die HKSA.

Elders is reeds oor sommige van hierdie genitiefsteologieë gehandel (Van der Westhuizen [1980a]:50-61; [1980b]:62-73; [1980c]:74-89; [1980d]:90-108). Ook oor die verskynsel van kontekstualisering op 'n wyse wat tot grondslag van die gemeenskapsteologieë dien, is reeds gehandel (Van der Westhuizen 1990:57-59).

Dit is tog nodig om op enkele saamvattende aspekte van die deelteologieë te wys. Indien die HKSA nie die verskil tussen die genoemde sekularisasie-teologieë en die reformatoriese teologie duidelik in die oog hou nie, sou dit fataal wees vir die waarheidsending.

Samevattend moet op die verskillende beskrywings en die verskillende benaminge van hierdie teologieë gewys word. Die verskillende beskrywings van hierdie teologieë wys eintlik almal op 'n gemeenskaplike eienskap van al hierdie teologieë. Die beskrywing 'geritiefsteologie' dui op die genitief of besitlike vorm as karakteristiek van dié teologieë. Die 's' in 'Bevrydingsteologie' of die 'van' in 'Teologie van Bevryding' dui byvoorbeeld op die inhoud van dié teologie dat dit eensydig oor bevryding, hoofsaaklik gewoonlik politieke bevryding, handel.

Die beskrywing 'gemeenskapsteologieë' beklemtoon dat dié teologieè elkeen uit 'n bepaalde gemeenskap en vir die bepaalde gemeenskap ontstaan. Om dieselfde rede kan dit 'kontekstuele teologieë' genoem word omdat die konteks, omstandighede of milieu van 'n bepaalde samelewing dié samelewingsteologieë vindren voed.

Juis omdat hierdie teologieë nie 'n omvattende teologie is nie maar net 'n deel van die Bybel en 'n deel van die mensdom se bestaan in 'n sisteem bring, is dit deelteologieë. Daarom is die onderskeid tussen hierdie teologieë en 'n ideologie byna onmoontlik. Hulle is self, indien nie ideologieë nie, ideologiese teologieë. Vroeër het die kerk met sektevorming te doen gekry. Dit is 'n soort kerkvorming rondom 'n teologiese punt. Vandag het die kerk ook te doen met deelteologievorming. Dit is 'n soort teologievorming rondom 'n kerklike situasie. Met 'kerk' word dan gewoonlik die betrokke gemeenskap bedoel. Vanselfsprekend staan die ekklesiologie en nog meer die Bybelse Christologie maar vermink in hierdie deelteologieë. Nie Jesus Christus wat bo van die Vader kom nie, maar Jesus Barabbas wat onder van die mens kom, word as gekruisigde middelaar nagejaag. 
'n Ideologie is 'n tipiese moderne godsdiens, 'n gesekulariseerde godsdiens. Die onderhawige teologieë kan dus ook sekularisasie-teologieë genoem word.

Die basiese werkmetode ten opsigte van die Bybel van hierdie teologieë is onderliggend aan die genoemde verskeidenheid identifiserende beskrywings en die hiernavolgende benaminge. Die Swartteologie poog om die Bybel aktueel te maak vir hetsy die armoedige of die regtelose of welke situasie ook al van die swart mense om substansie te verleen aan 'n sisteem of teologie wat uit die besondere situasie se behoeftes ontstaan. Op hierdie wyse word die besondere van die spesifieke situasie op die algemene betekenis van die Bybel van toepassing gemaak. In die Bybel word hoofsaaklik ook net die besondere bruikbare gedeeltes eensydig benut, byvoorbeeld dat God self intree vir die regtelose weduwees en wese, vir die armes 'n hulp is en so meer.

Op dieselfde induktiewe wyse van teologiefabrisering ontstaan die sogenaamde Bevrydingsteologie, Revolusieteologie, Witteologie, Ekologiese teologie, Feministiese teologie en so meer.

Die Bevrydingsteologie sleep die vryheidsgedagtes, veral die eksodusparadigma van die Bybel in die onderdukkingsituasie in om substansie aan sy ideologiese sisteem te gee. Die Revolusieteologie betrek op dieselfde induktiewe wyse gedagtes soos Jesus se sweepvlegting in die tempel, Petrus se swaardtrekkery en so meer in sy teologiese sisteem.

Witteologie wys weer op die rykdom van die Here (bv Ps 24) - Abraham, Salomo, Job, Johannes Markus se moeder Maria en andere in die Bybel - om gesitueerd in 'n voorspoedige (gewoonlik blanke) milieu 'n teologiese sisteem op te bou. Met die Ekologiese teologie betrek die bemiddelde Westerlinge die Bybelse gegewens oor die aarde en die omgewing en die mens se situasie daarin, op die besoedelingswêreld. Ironies genoeg, verloor die mens in hierdie teologie maklik sy Bybelse verhewenheid in ruil vir 'n blote skeppingsdeeltjie.

Die Feministiese teologie word geinisieer en gemotiveer deur die sfeer van die moderne vrou wat van haar sogenaamde agterstelling geëmansipeer wil word. Alles moet vervroulik word - selfs God en Christus. God is 'sy' en 'haar' en Christus is 'Christa' (Boelema 199(0:8). Aan die ander kant is dit juis in die kontekstuele teologieë, veral in die Bevrydingsteologie, dat die mens in alle opsigte, ook die vrou van haar vroulikheid, sogenaamd bevry moet word. Daar sou dan geen diskriminasie tussen ras, geslag, kleur en geloof ('race, sex, colour and creed') mag wees nie. Hierdie slagspreuk wat nog meer bekend is uit Marxistiese sfere, is in konflik met die evangelie. Die evangelie roep 'n persoon van 'n ander geloof ('creed') op tot bekering van sy nuttelose en daarom minderwaardige en geenwaardige afgodery. Dic bogenoemde diskriminasieslagspreuk wat gelykheid of egalitarisme tot 'n oral- 
en altydgeldende dogma verhef, bied konsekwent gesproke geen ruimte om vir 'n ander te sê dat sy geloof vir hom niks goeds inhou nie.

Die gelykheidsdogma van die Bevrydingsteologie gaan basies terug op die sogenaamde androgeniese mens (Van Oortmerssen 1990:5). Die androgeniese humanisme sien die vrou se diepste oorsprong in haar androgene of manlike wese. Ook dit sluit pragmatisties aan by die Bybel wat sê sy is uit die man geneem (Gen 2:23).

Omdat die mens in wese as van dieselfde kwaliteite, vermoëns en geslag gesien word, word homoseksualisme, vroueregte, vermanliking van vrouetitels (behalwe by prinsesse en koninginne en diere!), aborsie en kinderloosheid en so meer aanvaar, selfs as deel van menseregte geëis.

Die Bybel het inderdaad ' $n$ woord te spreek tot elke mens in elke groep en in elke omstandigheid. Dit is as Woord van God egter nie bedoel om by 'n gemeenskapsituasie tot substansie te dien om 'n humanistiese ideologie te versterk en aanvaarbaar te maak nie. Hierdie induktiewe metode het die bose reeds in die paradys aangewend, waar God se woord ingetrek is in die situasiebeoordeling van die verbode boom. Daarmee het die sondegebeure uitgebrei na die hele verhouding tussen God en mens, en mens en die ganse skepping, in plaas daarvan dat die mens in die paradys die boomgesprek deur die woord van God laat belig het - dan sou die volledige woord, die volledige opdrag, die volledige wil, die volledige bedoeling van God wat volledige gehoorsaamheid vereis, hierdie besondere situasie beredder het. So moet gelowiges vandag op deduktiewe wyse elke gemeenskapsituasie deur die volle waarheid van die Woord van God laat belig. Dit is ware kontekstualisering wat die gemeenskapkonteks onder die Woordbeligting bring en nie die Woord onder die konteksbehoeftes verduister nie. Die deelteologieë wat deels uit samelewingsgegewens en deels uit Bybelse inhoude gekonstrueer word, vind die hermeneutiese sleutel tot vertolking van die Bybel nie in die teks van die Bybel nie, maar in die konteks van die menslike of sosiale situasie.

Die NHKA en die HKSA moet bid en waak dat hulle en ander kerke in SuidAfrika nie ook in die versoeking van sogenaamde objektiwiteit, merietementaliteit en eksistensiedenke die Woord van die Here en die Here van die kerk verloën nie. Om toenemend kerk te wees is om met die waarheid in die wêreld meer te word.

Die vele oorsake van missionêre gebreke in die HKSA, soos ook by ander kerke, moet nie eerstens in eksterne nie maar in interne faktore gesoek word. Kerkwyse word deur kerkwese bepaal. 


\section{Literatuurverwysings}

Boelema, J 1990. Van Bazel via Utrecht naar Seoel. Getrouw Julie 1990, 7-9.

Hervormde Kerk in Suidelike Afrika sj. Kerkwet.

Nederduitsch Hervormde Kerk van Afrika 1989. Kerkwet. Pretoria:NHKA.

Van der Westhuizen, H G 1976. Aanbid God. Pretoria: HAUM.

--- 1977. Vertrou op God. Pretoria: HAUM.

--- [1980a]. Genitiefsteologieë. HTS $36 / 3 \& 4$, 50-61.

--- [1980b]. Ekumenisme. HTS 36/3 \& 4, $62-73$.

--- [1980c]. Ideologieë. HTS 36/3 \& 4, 74-89.

-.. [1980d]. Swart teologie. HTS 36/3 \& 4, 90-108.

--- 1982. Die kerk in die wêreld: 'n Bundel opstelle. Pretoria: HAUM.

--- 1990. Kerk en Kerstening. Pretoria: KITAL.

Van Rooy, K 1990. Gereformeerde teologiese Opleiding vir Afrika in die een-entwintigste eeu. In die Skriflig 24/3, 283-294.

Van Oortmerssen, A 1990. Bevrijdingstheologie en strafrecht. Getrouw Julie 1990, 4-7. 